\title{
TRANSFORMASI MENGGUNAKAN Agrobacterium tumefaciens PADA TUNAS DAUN Kalanchoe mortagei DAN Kalanchoe daigremontiana 1 DAN 2
}

\author{
Hamami Alfasani Dewanto ${ }^{1, *}$, Sony Suhandono ${ }^{2}$ \\ ${ }^{1}$ Universitas Muhammadiyah Purwokerto. J1. Raya Dukuh Waluh, Kembaran, Purwokerto, Jawa Tengah. 53182 \\ ${ }^{2}$ Institut Teknologi Bandung. Jl. Ganesha No.10, Lb. Siliwangi, Coblong, Kota Bandung, Jawa Barat. 40132 \\ *Alamat Korespondensi: sanidewanto@gmail.com
}

\begin{abstract}
Abstrak: Cocor bebek adalah tumbuhan sukulen yang mampu memproduksi tunas adventif (reproduksi vegetatif) pada tepian daunnya. Kemampuan reproduksi vegetatif ini menghasilkan tanaman yang sama dalam waktu yang singkat, sehingga memungkinkan untuk dijadikan sebagai bioreaktor protein rekombinan. Transformasi dilakukan menggunakan Agrobacterium tumefaciens pada tunas daun cocor bebek dari spesies Kalanchoe mortagei dan Kalanchoe daigremontiana. Optimasi dilakukan mencakup: galur A. tumefaciens, kerapatan optis dari kultur A. Tumefaciens, konsentrasi acetosyringone, teknik ko-kultivasi, pH medium dan komposisi medium ko-kultivasi. Hasil optimasi transformasi secara transien menunjukan bahwa perbedaan galur A. tumefaciens, kerapatan optis, konsentrasi acetosyringone menghasilkan ekspresi transien yang relatif sama secara kualitatif. Berdasarkan uji GUS teknik ko-kultivasi dengan infiltrasi vakum dan $\mathrm{pH}$ medium 5,5 menghasilkan ekspresi transien lebih baik dibandingkan dengan perendaman dan $\mathrm{pH}$ medium 7,0. Medium kokultivasi M9 menghasilkan ekspresi transien yang lebih baik dibandingkan dengan medium $1 / 2 \mathrm{MS} 0$. Tunas daun $K$. daigremontiana 2 menunjukan ekspresi transien yang lebih baik dibandingkan $K$. mortagei dan $K$. daigremontiana 1 .
\end{abstract}

Kata kunci: Transformasi, Kalanchoe sp, Agrobacterium tumefaciens

Abstract: Cocor bebek is a succulent plant that is capable of producing adventitious buds (vegetative reproduction) at the edges of the leaves. The ability has resulted in the production of identical plant in a short time, thus allowing it to be used as bioreactors for production of recombinant proteins. Transformation is done using Agrobacterium tumefaciens on its leaf buds from two spesies, Kalanchoe mortagei \& Kalanchoe Kalanchoe daigremontiana. Optimization is done by: A. tumefaciens strain, the optical density of the culture of A. tumefaciens, the concentration of acetosyringone, co-cultivation technique, the pH of the medium \& the composition of the co-cultivation medium. Optimization results by transient transformation shows that differences in strains of A. tumefaciens, optical density, concentration of acetosyringone produce transient expression is same qualitatively. Based on the GUS assay co-cultivation techniques with vacuum infiltration \& medium with pH 5.5 resulted in better transient expression than soaking in the medium \& medium with pH 7.0. Co-cultivation medium M9 produce transient expression better than the medium 1/2MSO. K. daigremontiana 2 leaf buds showed transient expression better than K. mortagei \& K. daigremontiana 1.

Keywords: Transformation, Kalanchoe sp, Agrobacterium tumefaciens

\section{PENDAHULUAN}

Produksi protein rekombinan telah menjadi topik yang ramai dibicarakan para peneliti. Tumbuhan menjadi salah satu pilihan inang terbaru untuk produksi protein rekombinan. Adapun yang menjadi pertimbangan menggunakan tumbuhan sebagai inang adalah biaya produksi yang lebih murah dibandingkan dengan hewan, mikroba dan sistem yang didasarkan pada kultur sel lainnya. Sistem tumbuhan dapat dibuat menjadi skala besar dengan cepat, tumbuhan tidak menghasilkan patogen hewan dan manusia. Selain itu tumbuhan dapat melakukan pelipatan protein, glikosilasi dan proses posttranslasi lainnya dengan tepat sehingga dihasilkan protein rekombinan yang sesuai. Kelebihan lainnya adalah sel tumbuhan dapat mengeluarkan produk proteinnya pada lingkungan untuk mengurangi degradasi dan meningkatkan stabilitasnya (Horn etal, 2004). Proses pemindahan informasi genetik pada tumbuhan dapat dilakukan melalui beberapa cara, diantaranya transformasi protoplasma, biolistik dan transformasi menggunakan Agrobacterium. Transformasi menggunakan Agrobacterium merupakan metode yang paling sering digunakan untuk men-transformasi tumbuhan. Tingkat keberhasilan metode transformasi ini dipengaruhi oleh beberapa faktor, diantaranya, galur bakteri, plasmid, media kultur, lamanya ko-kultivasi, acetosyringone, pelukaan, dan kompetensi sel inang untuk terinfeksi (Salas etal, 2001). Genus Kalanchoe meliputi kurang lebih 125 spesies yang memiliki bentuk daun dan pola perkembangan planlet yang bervariasi sehingga sangat berguna untuk penelitian regenerasi sel tumbuhan. Transformasi tunas pada dua jenis cocor bebek $K$. daigremontiana dan $K$. mortagei belum pernah dilaporkan. Pada penelitian ini, dilakukan optimasi transformasi tunas daun $K$. daigremontiana dan $K$. mortagei dengan menggunakan A. tumefaciens yang memiliki vektor ekspresi tumbuhan pBI 121 kosong dengan 
mengamati tingkat kebiruan ekspresi gen reporter GUS pada plasmid pBI 121.

\section{BAHAN DAN METODE}

Bahan

Tanaman cocor bebek spesies $K$. daigremontiana dan $K$. mortagei. Media pertumbuhan tanaman berupa campuran tanah dan pupuk kandang. Koloni tunggal A. tumefaciens galur LBA4404, AGL1, dan GV3101, vektor ekspresi pBI 121. Rifampicin, kanamycin, medium YEP (10 g/L yeast extract, 10 $\mathrm{g} / \mathrm{L}$, Bacto peptone, $5 \mathrm{~g} / \mathrm{L} \mathrm{NaCl}$ ) dan medium $\mathrm{M} 9$ (200 mL garam medium M9 $\left(64 \mathrm{~g} / \mathrm{L} \mathrm{Na}_{2} \mathrm{HPO}_{4}-7 \mathrm{H}_{2} \mathrm{O}\right.$ $\left.15 \mathrm{~g} / \mathrm{L} \mathrm{KH}_{2} \mathrm{PO}_{4}, 2,5 \mathrm{~g} / \mathrm{L} \mathrm{NaCl}, 5,0 \mathrm{~g} / \mathrm{L} \mathrm{NH}_{4} \mathrm{Cl}\right), 2$ $\mathrm{mL} / \mathrm{L} \mathrm{MgSO}_{4} 1 \mathrm{M}, 20 \mathrm{~mL}$ Glukosa 20\%, $100 \mu \mathrm{l} / \mathrm{L}$ $\mathrm{CaCl}_{2}$ 1M)). 3,5-Dimethoxy-4-Hydroxyacetopnenone (acetosyringone), dimetil sulfoksida, 0,5 $\mathrm{mM}$

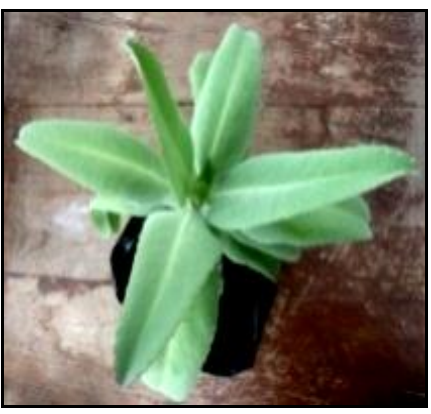

(A)

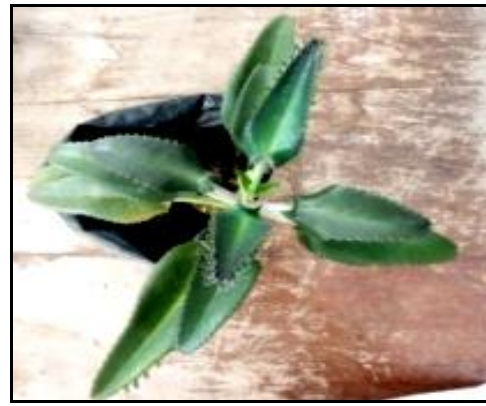

(B)

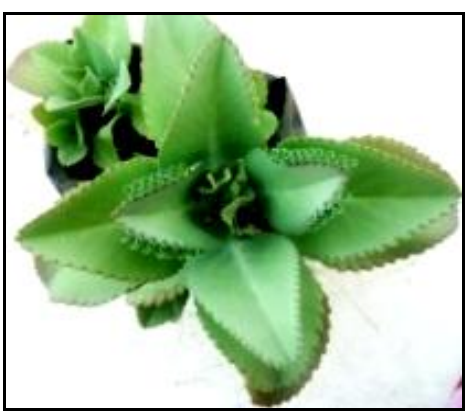

(C)

Gambar 1. Jenis Kalanchoe yang digunakan dalam penelitian: (A) K. Mortagei, (B) K. daigremontiana 1, (C) K. daigremontiana 2 .
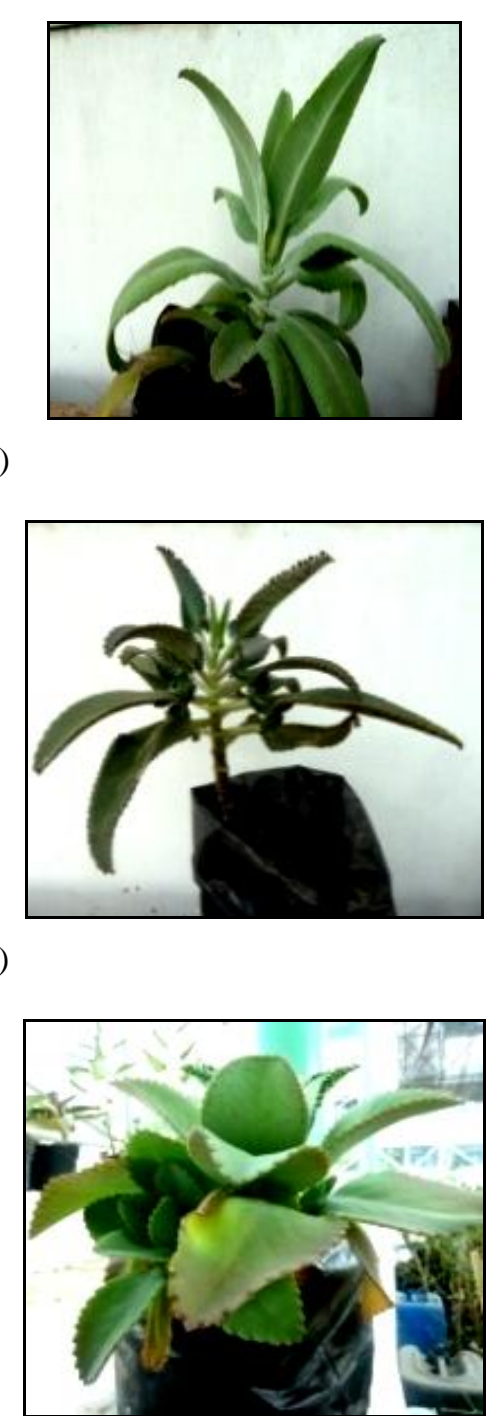

$\mathrm{K}_{3} \mathrm{Fe}(\mathrm{CN})_{6}, 0,5 \mathrm{mM} \mathrm{K}{ }_{4} \mathrm{Fe}(\mathrm{CN})_{6}, 0,3 \%$, Triton-X 100, $50 \mathrm{mM}$ buffer fosfat $\mathrm{pH}$ 7. Medium $1 / 2 \mathrm{MSO}$ (Murashige \& Skoog, 1962) dengan setengah konsentrasi garam dan vitamin, medium M9 (Sambrook et al. 1989)

\section{Pemeliharaan tanaman dalam rumah kaca}

Tanaman cocor bebek (Gambar 1) didapatkan disekitar daerah Bandung, Jawa Barat. Media pertumbuhannya berupa campuran tanah dan pupuk kandang dengan perbandingan 4:1. dipelihara dalam rumah kaca dengan penyinaran normal sinar matahari, suhu rumah kaca berkisar antara $19-33^{\circ} \mathrm{C}$. Penyiraman dilakukan dengan $\pm 300 \mathrm{~mL}$ air, dua kali dalam setiap minggu.

B)

C) 


\section{Optimasi transformasi tunas daun tanaman cocor} bebek

Tunas tanaman cocor bebek diambil dari rumah kaca. Tunas kemudian dicuci pada air mengalir selama kurang lebih 5-10 menit dan dikeringkan menggunakan kertas tisu, kemudian ditransformasi dengan A. tumefaciens yang mengandung pBI 121.

Transformasi vektor ekspresi pBI 121 kedalam $A$. tumefaciens menggunakan metode kalsium klorida (Dagert \& Ehrlich 1979). Koloni tunggal A. tumefaciens yang positif memiliki plasmid pBI 121 dicuplik dengan menggunakan tusuk gigi steril dan dimasukkan dalam 10-20 ml YEP cair dengan penambahan $50 \mathrm{mg} / \mathrm{L}$ antibiotik yang sesuai, kemudian diinkubasikan pada shaker dengan kecepatan $200 \mathrm{rpm}$ pada suhu ruang dalam kondisi gelap selama dua hari. $10 \%$ kultur ditambahkan pada kultur besar YEP yang mengandung $50 \mathrm{mg} / \mathrm{L}$ antibiotik yang sesuai. Pada saat mencapai kerapatan optis tertentu $\mathrm{OD}_{600}$, kultur dipanen dengan cara disentrifugasi dengan kecepatan $2700 \mathrm{rpm}$ selama 30 menit. Medium pertumbuhan kemudian diganti dengan medium ko-kultivasi dengan volume sama. Pada medium kokultivasi ditambahkan silwett L-77 0,02\%, dan acetosyringone kemudian digunakan untuk mentransformasi tunas daun cocor bebek. Optimasi secara berurut dilakukan mencakup: galur A. tumefaciens (LBA4404, GV3101, AGL1), kerapatan optis $\mathrm{OD}_{600}$ dari A. Tumefaciens $(0,50,7$ 0,9), konsentrasi acetosyringone (0, 20, 50, 100, 200) $\mu \mathrm{M}$, teknik introduksi A. tumefaciens (perendaman dan infiltrasi vakum), $\mathrm{pH}$ medium ko-kultivasi $(5,5$ dan 7,0$)$ dan komposisi medium ko-kultivasi $(1 / 2 \mathrm{MS} 0$ dan M9).

\section{Konfirmasi tunas tertransformasi secara transien dengan GUS Assay.}

Tunas yang telah selesai melewati periode kokultivasi selama dua hari, satu helai daun per tunasnya diambil dari dan dimasukan ke dalam larutan GUS. Komposisi larutan GUS untuk uji gen $\beta$-Glucoronidase adalah sebagai berikut: substrat berupa 5-Bromo-4-chloro-1H-indol-3-yl $\quad \beta$-D-

A

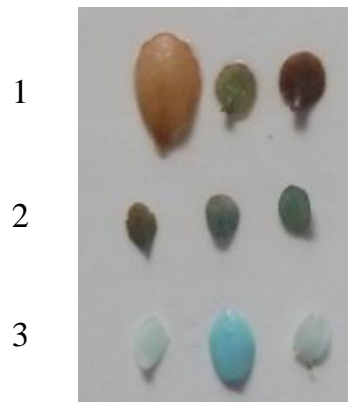

B

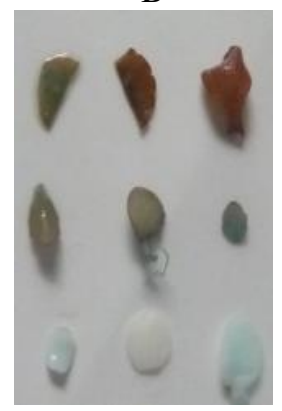

glucopyranosiduronic $\left(X-G l u c^{\circledR}\right) 1 \mathrm{mM}$ dilarutkan dalam dimetil sulfoksida (DMSO), 0,5 $\mathrm{mM}$ $\mathrm{K}_{3} \mathrm{Fe}(\mathrm{CN})_{6}, 0,5 \mathrm{mM} \mathrm{K}{ }_{4} \mathrm{Fe}(\mathrm{CN})_{6}, 0,3 \%$, Triton-X 100, $50 \mathrm{mM}$ buffer fosfat $\mathrm{pH}$ 7. Kemudian daun diinkubasi dalam inkubator pada suhu $37^{\circ} \mathrm{C}$ selama 1-2 hari (Sambrook et al. 1989).

\section{HASIL DAN PEMBAHASAN}

\section{Optimasi Transformasi Tunas Daun Tanaman}

\section{Cocor Bebek}

Optimasi transformasi transien pada tanaman cocor bebek dilakukan dengan menguji jumlah dan kondisi yang sesuai untuk berlangsungnya proses transformasi yang meliputi, galur A. tumefaciens, kerapatan optis, konsentrasi 3,5-Dimethoxy-4Hydroxyacetopnenone (acetosyringone), teknik introduksi A. tumefaciens (infiltrasi vakum, perendaman), $\mathrm{pH}$ media ko-kultivasi (5,5 dan 7), dan jenis media ko-kultivasi.

Optimasi yang pertama dilakukan adalah memilih galur A. tumefaciens yang memiliki tingkat infeksi tertinggi terhadap tanaman cocor bebek. Tingkat infeksi tertinggi ditunjukan dengan hasil ekspresi transien dari gen GUS melalui GUS Assay. Hasil penelitian pada tanaman cocor bebek dengan menggunakan tiga macam galur Agrobacterium (LBA4404, GV3101, AGL1) tidak menunjukkan keseragaman hasil transformasi dalam satu galur. Aida \& Shibata (1996) juga mendapatkan hal yang sama pada saat mengamati hasil transformasi $A$. tumefaciens galur LBA4404 pada tanaman cocor bebek $K$. blossfeldiana. Pengamatan yang dilakukan Aida \& Shibata (1996) mendapatkan tiga kelas aktifitas gen reporter GUS yaitu aktifitas tinggi, aktifitas rendah dan hampir tanpa aktifitas.

Pengamatan hasil GUS Assay yang ditunjukkan Gambar 2 memperlihatkan warna biru muda yang menunjukkan tingkat ekspresi gen reporter belum baik, karena warna GUS assay yang semestinya adalah warna biru indigo. Variasi virulensi yang menjadi kunci level ekspresi gen reporter GUS salah satunya disebabkan adanya perbedaan kemampuan sel bakteri untuk menempel pada sel tanaman atau

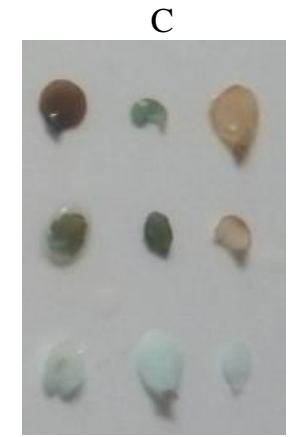

Gambar 2. Uji tansformasi transien pada tunas dengan perlakuan galur bakteri. Galur LBA4404 menghasilkan tingkat warna biru yang lebih baik pada $K$. daigremontiana 2 A : LBA4404, B : GV3101, C : AGL1, D : Kontrol. Baris 1: Kalanchoe mortagei, Baris 2: Kalanchoe daigremontiana 1, Baris 3: Kalanchoe daigremontiana 2, bar : $1 \mathrm{~cm}$. 
perbedaan kemampuan sel bakteri dan sel tanaman untuk mengkode protein yang berkaitan dengan mekanisme perpindahan T-DNA (Nam et al. 1997).

Gambar 2 juga memperlihatkan bahwa warna yang dihasilkan oleh hasil transformasi masingmasing galur berbeda. Karakter masing-masing galur berbeda didasarkan pada latar belakang kromosom yang menyusun mereka. Galur Agrobacterium yang ada dikembangkan dari dua isolat liar: C58 (Hamilton \& Fall 1971) dan Ach5 (Hoekema et al. 1983). Galur AGL1, dan GV3101 dikembangkan dari kromosom C58, sedangkan galur LBA4404 dikembangkan dari kromosom Ach5. Latar belakang kromosom yang berbeda ini menyebabkan galur Agrobacterium tertentu memiliki tingkat virulensi yang lebih tinggi dibandingkan dengan lainnya tergantung pada jenis inangnya, misalnya galur $\mathrm{C} 58 \mathrm{C} 1$ lebih cocok dalam aplikasi ekspresi transien pada lettuce, tomat dan arabidopsis (Wroblewski et al. 2005). Hal ini menjelaskan mengapa pada Gambar 2 warna biru yang dihasilkan oleh galur LBA4404 memiliki tingkat kebiruan yang lebih baik, meskipun tidak seragam, sedangkan tingkat ekspresi gen reporter GUS pada galur GV3101 dan AGL1 relatif sama. LBA4404 menghasilkan jumlah pucuk hidup terbanyak pada transformasi menggunakan daun tembakau (Salas et al. 2001). Kim et al. (2009) melaporkan bahwa tingkat ekspresi transien pada Arabidopsis menggunakan LBA4404 (octopine) 1,6 kali lebih tinggi dibandingkan menggunakan tipe nopaline dan 3,5 kali lebih tinggi dibandingkan dengan tipe succinamopine. Berdasarkan hasil yang didapatkan dan beberapa studi literatur maka $A$. tumefaciens galur LBA4404 digunakan untuk tahap optimasi selanjutnya.

Optimasi yang kedua dilakukan untuk menguji pengaruh kerapatan optis yang optimal untuk proses transformasi. Optimasi dilakukan dengan menggunakan nilai kerapatan optis yang berbeda, yaitu 0,$5 ; 0,7$ dan 0,9 . Hasil yang didapatkan pada optimasi kerapatan optis tidak jauh berbeda dengan hasil yang didapatkan pada optimasi galur $A$. tumefaciens. Hasil yang didapatkan tidak seragam

dalam satu perlakuan. Kerapatan optis menunjukkan kepadatan bakteri dalam medium. Semakin inggi nilai kerapatan optis semakin tinggi pula jumlah $A$. tumefaciens yang terkandung dalam medium. Gambar 3 memperlihatkan bahwa jumlah bakteri tidak berbanding lurus dengan hasil ekspresi gen reporter artinya semakin banyak bakteri tidak berbanding lurus dengan tingkat infeksi atau tingkat transformasi transien. Hal ini ditunjukkan pada gambar bahwa perlakuan dengan kerapatan optis $\mathrm{OD}_{600} \quad 0,9$ memiliki tingkat ekspresi gen reporter yang lebih rendah ditunjukkan pada warna hasil $G U S$ Assay pada $K$. daigremontiana 1 dan 2 jika dibandingkan dengan kerapatan optis $\mathrm{OD}_{600} \quad 0,7$. Perlakuan dengan kerapatan optis $\mathrm{OD}_{600} \quad 0,5$ juga menunjukkan tingkat kebiruan yang lebih rendah pada $K$. daigremontiana 1 dan 2 dibandingkan dengan kerapatan optis $\mathrm{OD}_{600} \quad 0,7$. Menurut Wroblewski et al. (2005) kepadatan suspensi sel sangat berpengaruh terhadap ekspresi transien pada Arabidopsis. Kepadatan sel bakteri dibawah $\mathrm{OD}_{600}$ 0,1 seringkali menghasilkan ekspresi transien yang rendah sedangkan kepadatan diatas $\mathrm{OD}_{600} \quad 1.0$ menyebabkan jaringan menjadi rapuh dan kuning. Berdasarkan hasil ini galur LBA4404 dan $\mathrm{OD}_{600} 0,7$ digunakan untuk proses optimasi transformasi selanjutnya.

Optimasi ketiga berkaitan dengan konsentrasi acetosyringone yang digunakan. Pada penelitian ini pemberian acetosyringone dilakukan pada medium ko-kultivasi dengan berbagai konsentrasi yaitu, 0, 20, 50, 100, dan $200 \mu \mathrm{M}$. Acetosyringone adalah suatu senyawa fenolik yang berperan dalam menstimulasi protein virA. VirA adalah sensor kinase histidin yang terikat membran. Sinyal senyawa fenolik (mis. acetosyringone) ditangkap oleh Agrobacterium melalui virA. VirA yang terautofosforilasi kemudian memindahkan gugus fosforilnya pada virG. Aktifnya virG ini kemudian menstimulasi transkripsi protein vir yang lain. VirG menstimulasi transkripsi dengan cara menempel pada sekuen 12 pasang basa lestari yang kaya akan basa AT pada bagian promoter (Pazour \& Das 1990).

C

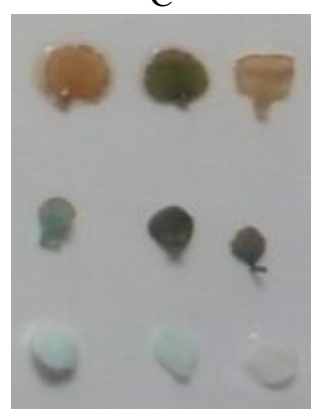

D

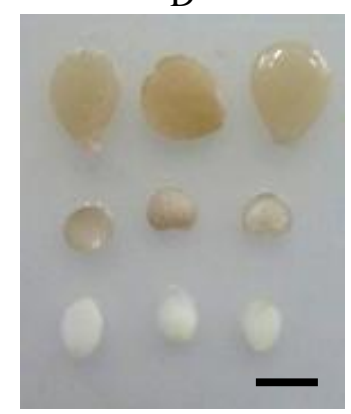

Gambar 3. Uji tansformasi transien pada tunas dengan perlakuan optical density. Perlakuan 0,7 menghasilkan warna biru yang lebih baik pada $K$. daigremontiana. A : 0,5 , B : 0,7 , C : 0,9 , D : Kontrol. Baris $1:$ Kalanchoe mortagei, Baris 2 : Kalanchoe daigremontiana 1, Baris $3:$ Kalanchoe daigremontiana 2, bar : $1 \mathrm{~cm}$. 


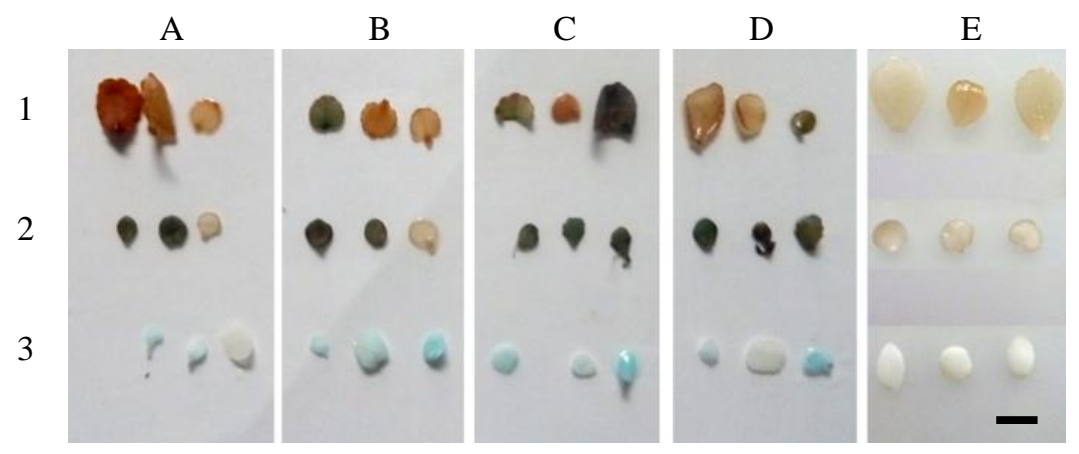

Gambar 4. Uji tansformasi transien pada tunas dengan perlakuan konsentrasi acetosyringone, tidak menunjukkan tingkat warna biru yang berbeda. A : $0 \mu \mathrm{M}, \mathrm{B}: 50 \mu \mathrm{M}, \mathrm{C}: 100 \mu \mathrm{M}, \mathrm{D}: 200 \mu \mathrm{M}$, E: Kontrol. Baris 1 : Kalanchoe mortagei, Baris 2 : Kalanchoe daigremontiana 1, Baris 3 : Kalanchoe daigremontiana 2, bar : $1 \mathrm{~cm}$.

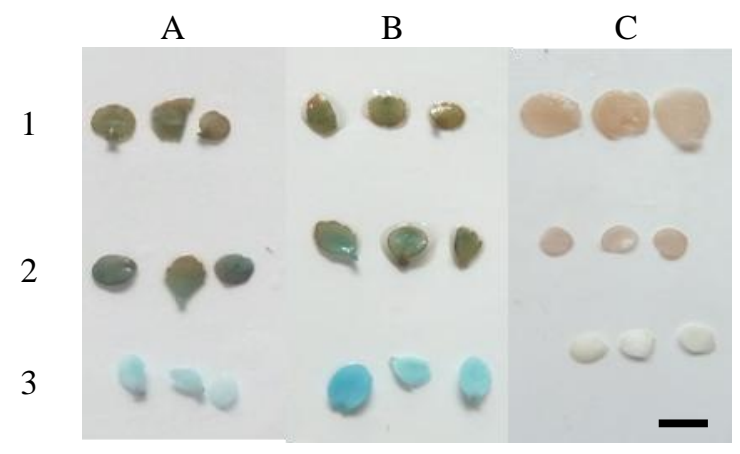

Gambar 5. Uji tansformasi transien pada tunas dengan perlakuan teknik introduksi A. tumefaciens. Perlakuan infiltrasi vakum menghasilkan tingkat warna biru lebih baik pada $K$. daigremontiana 2. A: perendaman B: infiltrasi vakum, C: kontrol. Baris 1: Kalanchoe Mortagei, Baris 2: Kalanchoe daigremontiana 1, Baris 3: Kalanchoe daigremontiana 2, bar: $1 \mathrm{~cm}$.

Hasil percobaan dengan menggunakan daun tunas adventif tidak menghasilkan perbedaan warna biru yang baik (Gambar 4). Warna biru yang tampak jika dibandingkan dengan perlakuan sebelumnya mengalami penurunan intensitas seperti yang teramati pada $K$. daigremontiana 2 , sedangkan pada $K$. daigremontiana 1 seperti yang ditunjukkan pada Gambar 4, sepuluh dari dua belas daun yang ditunjukkan mengalami browning yang lebih parah dibandingkan perlakuan galur dan kerapatan optis. Hal ini menandakan ekspresi gen vir tidak meningkat secara signifikan. Hasil yang sama pernah dilaporkan oleh Dixon et al. (2002) yang mendapatkan hasil bahwa penambahan acetosyringone tidak menunjukan perbedaan tingkat virulensi yang berarti pada Agrobacterium dengan kromosom Ach5 (LBA4404) menggunakan B. campestris dan G. max.

Penelitian ini juga mendapatkan bahwa Agrobacterium dengan kromosom Ach5 (LBA4404) tidak menunjukan perbedaan tingkat virulensi yang berarti pada cocor bebek ketika diberi perlakuan dengan konsentrasi acetosyringone yang berbeda. Hal ini mengindikasikan bahwa ada variabel lain yang berperan atau berperan bersama dengan acetosyringone dalam proses interaksi Agrobacterium dan inang. Fenol mutlak dibutuhkan dalam aktivasi gen vir, meskipun fenol secara alami terdapat pada tumbuhan tingkat tinggi, penambahan yang spesifik berguna untuk beberapa spesies dan genus (Dixon et al. 2002). Hasil biru yang relatif tidak berbeda pada pengamatan langsung untuk masing-masing perlakuan pada percobaan ini bukan berarti acetosyringone tidak berperan dalam transformasi, tetapi lebih disebabkan oleh kondisi lain yang menyebabkan Agrobacterium tidak dapat secara optimal menginfeksi sel tumbuhan. Batas atas konsentrasi acetosyringone sebesar $200 \mu \mathrm{M}$ diambil berdasarkan penelitian Stachel et al. (1985) yang menemukan bahwa konsentrasi acetosyringone 200 $\mu \mathrm{M}$ tidak beracun secara signifikan pada sel Agrobacterium. Optimasi selanjutnya menggunakan konsentrasi $100 \mu \mathrm{M}$ didasarkan pada data sekunder dari penelitian Jung et al. (2009) yang mendapatkan hasil bahwa pada konsentrasi acetosyringone $200 \mu \mathrm{M}$ mampu mentransformasi $K$. pinnata secara stabil untuk produksi $\mathrm{ScFv}$.

Optimasi keempat adalah menguji teknik introduksi A. tumefaciens. Dua cara yang digunakan dalam penelitian ini dalam mengintroduksi $A$. tumefaciens. Pertama adalah dengan perendaman dalam medium cair yang mengandung A. tumefaciens LBA4404, $\mathrm{OD}_{600}$ 0,7 dan acetosyringone $100 \mu \mathrm{M}$. 
Kedua adalah dengan infiltrasi vakum dalam medium cair yang mengandung A. tumefaciens LBA4404, $\mathrm{OD}_{600} 0,7$ dan acetosyringone $100 \mu \mathrm{M}$.

Gambar 5 menunjukkan hasil yang kurang optimal dalam uji GUS ditandai dengan tingkat kebiruan dari ekspresi glukoronidase pada perlakuan perendaman yang dapat dilihat jelas pada $K$. Daigremontiana 2. Hal ini diduga berkaitan dengan interaksi bakteri dengan sel tumbuhan yang kurang optimal. Hasil perlakuan introduksi menggunakan infiltrasi vakum menunjukkan hasil yang lebih baik jika dilihat dari ekspresi gen reporter pada $K$. Daigremntiana 2. Proses infiltrasi vakum memaksa bakteri untuk dapat masuk kedalam jaringan pengangkut pada tumbuhan, sehingga interaksi antara Agrobacterium dengan sel tanaman berlangsung lebih baik. Hasil interaksi yang baik ini menyebabkan tingkat infeksi yang lebih tinggi yang ditunjukkan dengan ekspresi GUS yang lebih tinggi pada $K$. Daigremntiana. Optimasi infiltrasi vakum yang sesuai dengan kemampuan tunas cocor bebek adalah $300 \mathrm{mmHg}$ selama 15 menit pada $K$. daigremontiana dan 5 menit pada $K$. mortagei. Ukuran waktu tersebut dilihat dari tingkat kerusakan yang dialami daun selama proses vakum yang mengakibatkan tunas mati. Daun K. mortagei secara morfologi memiliki lapisan kutikula yang lebih tipis sehingga kurang lebih tiga kali lebih sensitif terhadap proses vakum dibandingkan dengan $K$. daigremontiana. Berdasarkan dengan hasil ini maka infiltrasi vakum dalam medium cair yang mengandung A. tumefaciens LBA4404, $\mathrm{OD}_{600}$ 0,7 dan acetosyringone $100 \mu \mathrm{M}$ digunakan untuk proses optimasi berikutnya.

Optimasi kelima berkaitan dengan derajat keasaman media tumbuh bakteri yaitu YEP dan media ko-kultivasi yaitu 1/2MS0. Ekspresi transien pada daun tunas menunjukkan warna biru yang lebih baik pada tanaman yang diinfeksi dengan menggunakan A. tumefaciens yang ditumbuhkan pada medium asam (Gambar 6). Perbedaan warna kebiruan ini disebabkan karena perbedaan level ekspresi pada virG dari A. tumefaciens. Hasil yang serupa didapatkan oleh Yuan et al. (2007) yang mendapatkan bahwa level ekspresi virG dari $A$. tumefaciens yang ditumbuhkan pada medium asam naik sebanyak dua kali lipat lebih, sedangkan aktivitas $\beta$-Glucoronidase meningkat dari 198 unit miller pada kondisi netral ke 723 unit miler pada kondisi asam. Hal lain yang terinduksi oleh keberadaaan kondisi asam ini adalah ekspresi dari virE0, -E1, -H1, - $\mathrm{H} 2$ yang berperan dalam proses transformasi.

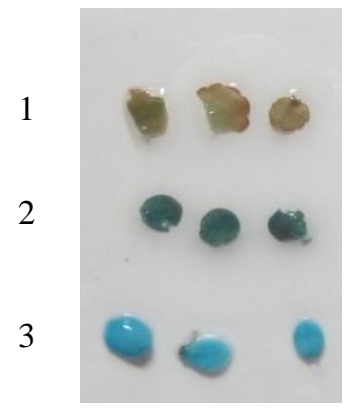

B

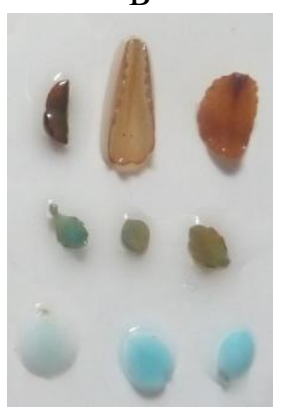

$\mathrm{C}$

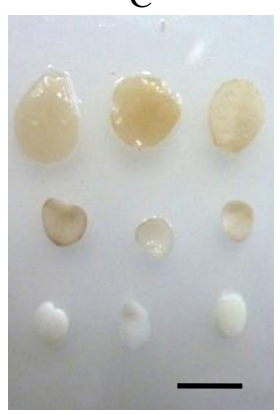

Gambar 6. Uji tansformasi transien pada tunas dengan perlakuan $\mathrm{pH}, \mathrm{A}: \mathrm{pH}$ 5,5, B : pH 7, C: kontrol. Baris 1 : Kalanchoe Mortagei, Baris 2 : Kalanchoe daigremontiana 1, Baris 3 : Kalanchoe daigremontiana 2, bar : $1 \mathrm{~cm}$.

A

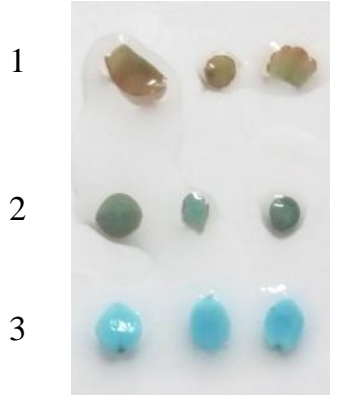

B

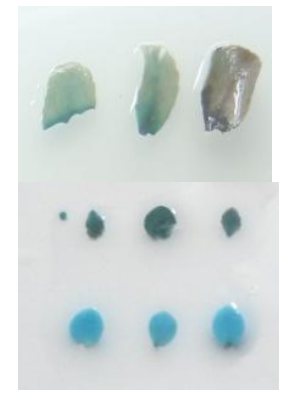

$\mathrm{C}$

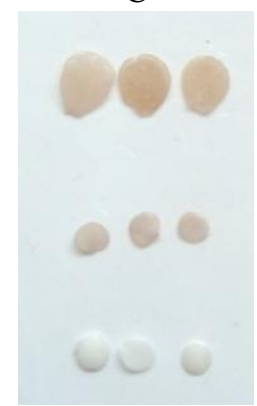

Gambar 7. Uji tansformasi transien pada tunas dengan perlakuan medium ko-kultivasi, A: $1 / 2$ MS0, B: M9, C: Kontrol. Baris 1: Kalanchoe Mortagei, Baris 2: Kalanchoe daigremontiana 1, Baris 3: Kalanchoe daigremontiana 2, bar: $1 \mathrm{~cm}$. 
Warna biru yang cukup mencolok pada $K$. daigremntiana 1 dan 2 pada tahap ini salah satunya disebabkan oleh melimpahnya aktivasi ekspresi protein vir pada kromosom A. tumefaciens. Hal ini terjadi karena induksi transkripsi gen vir hanya akan terjadi pada kondisi yang asam, pada $\mathrm{pH}$ sekitar 5,5, yang merupakan $\mathrm{pH}$ umum pada rizosfer (Fierer \& Jackson 2006). Selain itu keberadaan senyawa fenolik (acetosyringone) yang terdapat dalam media diduga mengaktivasi promotor virG bagian distal, sedangkan kondisi asam secara tersendiri menginduksi promoter virG bagian proximal, yang berefek pada meningkatnya level ekspresi virG (Mantis \& Winan 1992). Aktivasi virG ini melibatkan aktivasi sistem yang lain yaitu chvG-chvI yang terdapat pada kromosom Agrobacterium. Sistem chvG-chvI ini kemudian diketahui berperan penting dalam pembentukan tumor dan pertumbuhan bakteri pada kondisi asam.

Hasil percobaan ini menunjukan bahwa Agrobacterium yang diperlakukan dengan $\mathrm{pH}$ rendah menghasilkan tingkat warna kebiruan yang lebih tinggi pada GUS assay dibandingkan pada $\mathrm{pH}$ netral. Mantis \& Winan (1993) mendapatkan data bahwa 152 gen pada $A$. tumefaciens terekspresi dua kali lipat atau lebih pada $\mathrm{pH} 5,5$.

Kondisi fisiologis A. tumefaciens dipengaruhi besarnya $\mathrm{pH}$ lingkungan. Saat terjadi perubahan $\mathrm{pH}$ A. tumefaciens akan memberikan respon yang komplek untuk mempertahankan $\mathrm{pH}$ dalam selnya tetap netral atau mendekati netral, kondisi ini dinamakan homeostasis $\mathrm{pH}$. pH 5,5 memang mempunyai beberapa kelebihan seperti melimpahnya ekspresi protein virulensi $A$. tumefaciens yang menyebabkan tingginya level ekspresi dari gen reporter. Tetapi disisi lain suasana $\mathrm{pH} \quad 5,5$ mempengaruhi kondisi fisiologis A. tumefaciens yang menyebabkan turunnya kecepatan pertumbuhannya. A. tumefaciens yang tumbuh pada medium netral memiliki laju pertumbuhan yang lebih cepat dibandingkan dengan $A$. tumefaciens yang tumbuh pada medium asam. A. tumefaciens yang tumbuh pada medium netral mencapai $\mathrm{OD}_{600} 0,7$ kurang lebih selama 8-12 jam sedangkan pada medium asam $A$. tumefaciens mencapai kepadatan yang sama kurang lebih selama 12-24 jam. Menurut Yuan et al. (2007) lambatnya laju pertumbuhan ini disebabkan $A$. tumefaciens yang tumbuh pada kondisi asam akan menekan aktivasi gen-gen yang berkaitan dengan metabolisme sel, respirasi, transfer elektron dan sintesis makromolekul. Meskipun memiliki konsekuensi dengan laju pertumbuhan A. tumefaciens yang lebih lambat $\mathrm{pH}$ 5,5 digunakan untuk proses optimasi selanjutnya bersana dengan kondisi galur $A$. tumefaciens $\mathrm{LBA} 4404, \mathrm{OD}_{600} 0,7$ dan acetosyringone $100 \mu \mathrm{M}$

Optimasi yang terakhir adalah mengoptimasi medium ko-kultivasi. Medium ko-kultivasi adalah medium yang digunakan untuk menumbuhkan bersama-sama $A$. tumefaciensdan tanaman sehingga medium ini harus dapat mendukung kebutuhan hidup antara dua organisme yang berbeda. Kondisi yang optimal yang diciptakan medium ko-kultivasi akan memacu proses interaksi antara naiknya tingkat virulensi dari A. tumefaciens dan melemahnya pertahanan tanaman sehingga lebih mudah untuk diinfeksi oleh A. tumefaciens. Medium ko-kultivasi yang digunakan adalah medium 1/2MS0 dan M9. Medium 1/2MS0 adalah medium yang umum digunakan dalam kultur jaringan tumbuhan sedangkan medium M9 adalah medium pertumbuhan bakteri.

Hasil pengamatan menunjukkan bahwa pada medium ko-kultivasi M9 didapatkan warna biru yang lebih baik dibandingkan dengan medium ko-kultivasi 1/2MS0 (Gambar 7). Bahkan pada K. Mortagei yang dari awal proses optimasi tidak pernah menunjukan hasil yang positif, pada optimasi ini menunjukkan warna biru yang cukup baik. Warna biru dari ekspresi gen reporter lebih terlihat jelas pada $K$. Daigremontiana 1 dan 2. Hal ini kemungkinan disebabkan karena pada medium M9 memiliki sumber karbon yang berbeda dengan medium 1/2MS0. Medium M9 menggunakan glukosa sebagai sumber karbonnya sedangkan pada medium MS menggunakan sukrosa sebagai sumber karbonnya. Kandungan glukosa ini menyebabkan adanya gerak kemotaksis bakteri menuju sel tanaman (Loake et al. 1988)

Analisis sekuen dari chvE A. tumefaciens menunjukkan bahwa chvE homolog terhadap protein pengikat gula pad E. coli (Huang et al.. 1990). Cangelosi et al. (1990) melaporkan bahwa chvE adalah protein pengikat gula yang memediasi proses kemotaksis dan induksi gen vir terhadap keberadaan glukosa, galaktosa dan gula yang lain. Ekspresi virB, $-\mathrm{C}$, -D, -E, dan $-\mathrm{F}$ terinduksi pada level transkripsi oleh struktur yang berhubungan dengan senyawa fenol seperti acetosyringone dan diduga memiliki potensi terinduksi oleh monosakarida eksogen dan kondisi lingkungan seperti $\mathrm{pH}$ dan suhu (Cangelosi et al. 1990). Protein chvE memiliki tingkat homologi yang tinggi terhadap protein pengikat gula (galactose-glucose-binding protein (GBP)) pada Escherichia coli (Huang et al. 1990), akan tetapi memiliki perbedaan spektum monosakarida yang terikat pada masing-masing protein. Keberadaan $A$. tumefaciens pada daerah luka menyebabkan kemotaksis yang dimediasi oleh chvE menuju monomer dinding, kemudian bakteri dapat menempel pada sel tanaman dan ekspresi gen vir menjadi terinduksi dengan adanya senyawa fenolik dan gula yang dikeluarkan oleh sel tanaman (Hahn et al. 1989).Transkripsi dari gen vir dapat diinduksi dengan berbagai macam senyawa fenolik salah satu contohnya adalah acetosyringone (Stachel et al. 1985), dan beberapa macam gula yang bekerja secara sinergis dengan senyawa fenolik (Cangelosi et al. 1990). pH asam dibutuhkan untuk ekspresi optimal dari gen vir (Stachel et al. 1986). Fakta-fakta yang 
disebutkan diatas menunjukan bahwa terdapat korelasi yang tinggi antara senyawa fenol, gula dan $\mathrm{pH}$.

Tiga variabel optimasi yang menentukan terbentuknya warna biru yang lebih baik pada ekstresi transien pada penelitian ini adalah infiltrasi vakum, $\mathrm{pH}$ media tumbuh asam dan sumber karbon bakteri berupa glukosa. Infiltrasi vakum memberikan hasil yang lebih baik dibandingkan dengan perendaman karena interaksi bakteri dengan sel tanaman yang lebih besar.pH asam berperan bersama dengan glukosa untuk memperkuat sinyal yang dihasilkan karena keberadaan acetosyringone, dengan cara berinteraksi dengan protein virA periplasmik dan membuat daerah kinase sensor virA sitoplasma menjadi oversensitif terhadap acetosyringone.

Tanpa keberadaan acetosyringone pengaruh $\mathrm{pH}$ asam dan glukosa menjadi tidak bermakna (McCullen \& Binns. 2006). Warna biru yang lebih baik pada $K$. daigremontiana 2 diduga berkaitan dengan produksi senyawa fenolik yang rendah dibandingkan dengan $K$. mortagei dan $K$. daigremontiana 1, hal ini dapat diamati dari timbulnya warna kecoklatan dan tekstur daun yang lebih keras pasca transformasi. Kondisi pada $K$. daigremontiana 2 didukung laporan Tkalec et al. (2012) yang menyatakan bahwa produksi fenolase tidak meningkat secara signifikan pada saat terjadi infeksi Agrobacterium pada $K$. daigremontiana. Tetapi belum ada penjelasan fenomena perbedaan produksi senyawa fenolik antara $K$. daigremontiana 1 dan $K$. daigremontiana 2 meskipun satu spesies, kemungkinan karena $K$. daigremontiana 1 telah memiliki warna yang lebih gelap dari $K$. daigremontiana 2 tetapi hal ini perlu kajian lebih lanjut.

\section{KESIMPULAN}

Profil transformasi terbaik berdasarkan uji ekspresi transien menggunakan gen GUS adalah menggunakan $K$. digremontiana 2, galur $A$. tumefaciens LBA 4404 yang ditumbuhkan pada $\mathrm{pH}$ 5,5 dengan metode infiltrasi vakum dengan kepadatan bakteri yang diukur pada panjang gelombang $600 \mathrm{~nm}$ sebesar 0,7 yang mengandung konsentrasi acetosyringone $100 \mu \mathrm{M}$, dengan medium ko-kultivasi M9.

\section{DAFTAR PUSTAKA}

Aida, R. \& Shibata, R. (1996). Transformation of Kalanchoe blossfeldiana mediated by Agrobacterium tumefaciens and transgene silencing. Plant Science. 121(2): 175-185

Cangelosi, G.A., Ankenbauer, R.G. \& Nester E.W. (1990). Sugars induce the Agrobacterium virulence genes through a periplasmic binding protein \& a transmembrane signal protein. Proceedings of the National Academy of Sciences USA. 87: 6708-6712
Dagert, M. \& Ehrlich, S. (1979). Prolonged incubation in calcium chloride improves the competence of Escherichia coli cells. Gene. 6 (1): $23-28$

Dixon, R.A., Achnine, L., Kota, P., Liu, C.J., Reddy, M.S.R. \& Wang, L. (2002). The phenylpropanoid pathway \& plant defense a genomics perspective. Molecular Plant Pathology. 3: 371-390

Fierer, N. \& R. B. Jackson. (2006). The diversity \& biogeography of soil bacterial communities. Proceedings of the National Academy of Sciences USA. 103: 626-631

Hahn, M.G., Bucheli, F., Cervone, F., Doares, S.H., O'Neill, R.A., Darvill, A. \& Albershelm, P. (1989). Roles of cell wall constituents in plantpathogen interactions. In Plant-Microbe Interactions: Molecular and Genetic Perspectives, Vol. 3. T. Kosuge \& E.W. Nester (eds). New York: McGraw-Hill. pp. 131-181.

Hamilton, R.H. \& Fall, M.Z. (1971). The loss of tumor-initiating ability in Agrobacterium tumefaciens by incubation at high temperature. Cellular and Molecular Life Sciences. 27(2): 229-230.

Hoekema, A., Hirsch, P.R., Hooykaas, P.J.J. \& Schilperoort, R.A. (1983). A binary plant vector strategy based on separation of vir- \& T-region of the Agrobacterium tumefaciens Ti-plasmid. Nature. 303: 179-80

Horn, M.E, Woodard, S.L, \& Howard, J.A. (2004). Plant molecular farming: systems \& products. Plant Cell Rep, 22, 711-20

Huang, M.L., Cangelosi, G.A., Halperin, W. \& Nester, E.W. (1990). A chromosomal Agrobacterium tumefaciens gene required for effective plant signal transduction. Journal of Bacteriology. 172(4): 1814-1822.

Jung,Y., Rhee, Y., Auh,C.K., Shim, H.K., Choi, J.J., Kwon, S.T., Yang, J.S., Kim, D., Kwon, M.H., Kim, Y.S. \& Lee, S. (2009). Production of recombinant single chain antibodies $(\mathrm{scFv})$ in vegetatively reproductive Kalanchoe pinnata by in planta transformation. Plant Cell Reports. 28(10): 1593-1602.

Kim, M.J., Baek, K. \& Park, C.M. (2009). Optimization of conditions for transient Agrobacterium-mediated gene expression assays in Arabidopsis. Plant Cell Reports. 28(8): 1159-1167

Loake, G.J., Ashby, A.M. \& Shaw, C.H. (1988) Attraction of Agrobacterium tumefaciens C58 towards Sugars Involve A Highly Sensitive Chemotaxis System. Journal of General Microbiology. 134: 1427-1432.

Mantis, N. J., \& S. C. Winans. (1992). The Agrobacterium tumefaciens vir gene transcriptional activator virG is transcriptionally induced by acid $\mathrm{pH} \&$ other stress stimuli. Journal of Bacteriology. 174(4): 1189-1196. 
McCullen, C.A. \& Binns, A.N. (2006). Agrobacterium tumefaciens and plant cell interactions and activities required for interkingdom macromolecular transfer. Annual Review of Cell and Developmental Biology. 22: 101-127..

Murashige, T. \& Skoog, F. (1962). A revised medium for rapid growth and bio assays with tobacco tissue cultures. Physiologia Plantarum. 15(3): 473-497

Nam, J., Matthysse, A.G. \& Gelvin, S.B. (1997). Differences in susceptibility of Arabidopsis ecotypes to crown gall disease may result from a deficiency in T-DNA integration. Plant Cell. 9: 317-333

Pazour, G.J., \& Das, A. (1990). Characterization of the virG binding site of Agrobacterium tumefaciens. Nucleic Acid Research. 18: 69096913

Sambrook, J., Fritsch E. F., \& Maniatis T. (1989). Molecular Cloning: A Laboratory Manual, 2nd Edition. New York: Cold Spring Habor Laboratory Press.

Salas, M.G., Park, S.H., Srivatanakul, M. \& Smith, R.H. (2001). Temperatue influence on stable TDNA integration in plant cells. Plant Cell Reports. 20(8): 701-705.

Stachel, S.E., Messens, E., Van Montagu, M. \& Zambryski, P. (1985). Identification of the signal molecules produced by wounded plant cells that activate T-DNA transfer in Agrobacterium tumefaciens. Nature. 318: 62429

Stachel, S.E., Nester, E.W. \& Zambryski, P.C. (1986). A plant cell factor induces Agrobacterium tumefaciens vir gene expression. Proceedings of the National Academy of Sciences USA. 83: 379-83

Tkalec, M., Car, D., Gospočić, J., Križaić, I., Duž, K. and Vidaković-Cifrek, Ž. (2012). Response of Kalanchoe daigremontiana to wounding and infection with Agrobacterium tumefaciens. Periodicum Biologorum. 114(1): 83-90.

Wroblewski, T., Tomczak, A. \& Michelmore, R., (2005). Optimization of Agrobacteriummediated transient assays of gene expression in lettuce, tomato and Arabidopsis. Plant Biotechnology Journal. 3(2): 259-273.

Yuan, Z.C., Liu, P., Saenkham, P., Kerr, K. \& Nester, E.W. (2008). Transcriptome profiling and functional analysis of Agrobacterium tumefaciens reveals a general conserved response to acidic conditions $(\mathrm{pH} 5.5)$ and a complex acid-mediated signaling involved in Agrobacterium-plant interactions. Journal of Bacteriology. 190(2): 494-507. 